\title{
NUTRITION REQUIREMENT OF CULTURED ABALONE POST LARVAE AND JUVENILES: A REVIEW
}

\author{
Wa Iba*)
}

\begin{abstract}
Abalone aquaculture attracts wide attention nowadays because of its high market value and depleted of wild stocks. China and Japan are the main producer of abalone from aquaculture followed by other countries such as New Zealand, Australia and US. Most of cultured abalone are temperate species but considerable research efforts have been made to culture tropical abalone in the Philippines, Thailand, and Indonesia. Most of abalone culture still depends on natural food but recent studies have been conducted to develop artificial diet for abalone. This will not only reduce wild harvest of macrolagae but also develop high nutrition diet at low cost. Successful abalone aquaculture is determined by correct nutrition supplement in the diet. As other cultured animal, abalone requires balanced nutrition of carbohydrate, protein, lipid, vitamins, and minerals. As herbivores, abalone can utilize carbohydrate efficiently as energy source and thus only requires low level of protein (range from $27 \%-40 \%$ ). Lipid requirements range from $3 \%-5 \%$ while some minerals such as calcium and phosphorus in artificial feed are only needed in small amount, $0.5 \%$ of calcium in diets and $0.7 \%$ of phosphorus in the diet can improve the growth rate of abalone. There is not available information of vitamin supplementation in the diet but it is suggested that natural food meets the requirement.
\end{abstract}

\section{KEYWORDS: abalone, nutrition, post larvae, juvenile}

\section{INTRODUCTION}

\section{Geographic Distribution and Cultured Species Worldwide}

Abalones are worldwide distributed and known for their delicate meat (Najmudeen \& Victor, 2004). Abalones are herbivorous gastropods (family Haliotidae) common on coastal reefs in temperate waters (McShane \& Smith, 1988). They belong to the family Haliotidae and the genus Haliotis, which means sea ear, referring to the flattened shape of the shell (Ebert, 1992). Nearly 100 species of abalone are distributed throughout the world's oceans. Large abalones are mainly distributed in the temperate zone, while small species are typically found in the tropics. Ten species are considered of commercial value, and mainly occur in
Korea, Japan, Mexico, South Africa, Southern Australia, New Zealand, United States of America, and China. Commercial species widely known include Haliotis ruber in Australia, $\mathrm{H}$. iris in New Zealand and $H$. midae in South Africa (FAO, 1990). Recent data, however, showed that more than 20 species are classified as commercially important (Table 1) Jarayabhand \& Paphavasit, 1996).

Over 90 species occurs in the west coast of North America, eastern and southern coasts of Asia, Pacific Islands, Australia, New Zealand, Africa, and Europe (Castell, 2003). Six species of abalones are naturally distributed along the coast of China, Haliotis discus hannai Ino, $\mathrm{H}$. diversicolor Reeve, $H$. asinina Linnaeus, $H$. ovina Gmelin, $H$. planata Sowery, $H$. varia Linnaeus, and H. clathrata Reeve. However,

") Faculty of Fisheries and Marine Science Haluoleo University, Southeast Sulawesi, Indonesia 
Table 1. Commercially important of abalone species Jarayabhand \& Paphavasit, 1996)

\begin{tabular}{llc}
\hline \multicolumn{1}{c}{ Scient ific name } & \multicolumn{1}{c}{ Common name } & SL ( mm) \\
\hline H. rufescens & Red abalone & $>275$ \\
H. fulgens & Red, southern green or blue & $125--200$ \\
H. corrugate & Pink or corrugated & $150--175$ \\
H. sorenseni & White or Sorensen & $125--200$ \\
H. assimilis & Threaded & $<100$ \\
H. cracherodii & Black & $75--125$ \\
H. walallensis & Flat or Northern green & $75--125$ \\
H. kamtschatkana & Pinto & 100 \\
H. discus hannai & Ezo awabi & $180--200$ \\
H. discus & Kuro awabi, oni or onigai & 200 \\
H. diversicolor supertexta & Tokobushi & 50 \\
H. gigantea & Madaka & 250 \\
H. sieboldii & Megae & 170 \\
H. asinina & Mimigai, donkey's ear & $70--100$ \\
H. rubra & Black lip & $120--140$ \\
H. laevigata & Green lip & $130-140$ \\
H. roei & Roe's & $70--80$ \\
H. iris & Paua or black & 170 \\
H. australis & Silver or queen paua & 125 \\
H. virginea & Virgin & 70 \\
H. tuberculata & Ormer & 120 \\
H. midae & Perlemon & 90 \\
\hline & &
\end{tabular}

only two species have been cultured i.e. $\mathrm{H}$. discus hannai and $H$. diversicolor, whereas culture of $H$. asinina has drawn considerable attention in recent years (Zhang et al., 2004). Ten species are distributed in the Pacific Coast of North America but only three species are commercially important. They are the red (Haliotis rufescens), the green (H. fulgens), and the pink $(H$. corrugata) abalones. Research into cultivation techniques has been conducted on the black ( $H$. cracherodii) and white abalones $(H$. sorenseni) (Ebert, 2001).

Naturally, abalones are found at depths up to 30 metres in the intertidal zone. Abalones have their maximum population density at depths ranging between $3-10$ metres where seaweeds, their natural food, grow abundantly and can tolerate temperature range between $2^{\circ} \mathrm{C}-30^{\circ} \mathrm{C}$ (FAO, 1990). They posses high commercial value in seafood market not only for their meats but also for their shells. Wild harvested abalones particularly designed to fulfill the demand in US, Canadian, Japanese, Hong
Kong, and New Zealand markets (Oakes \& Ponte, 1996). Abalone shells are also sold to shell collectors and as souvenirs, and are used in making jewelery (Ebert, 1992). Abalones are marketed in various forms in those countries from live to frozen product (Table 2, Oakes \& Ponte, 1996).

\section{Size and Value of the Industry}

Due to declining wild stock of abalone, cultivation of abalone started to flourished (Ebert \& Houk, 1984; Stevens, 2003). In 1984, the cultivation of abalone, Haliotis spp., has spanned nearly a 50-year period (Ebert \& Houk, 1984). It means that by the year of 2006 , the abalone aquaculture has been conducted for 72 year. Abalone cultivation is not only aimed to commercial market but also to enhance wild stock population (Ebert \& Houk, 1984; Awaji \& Hamano, 2004). Aquaculture industry of abalone mainly occurs in Japan, Australia, New Zealand, The United States, Mexico, and South Africa (Jarayabhand \& Paphavasit, 1996). Re- 
Table 2. Product of abalone sold in the market, H. rufescens in particular (From Oakes \& Ponte, 1996)

\begin{tabular}{|c|c|c|}
\hline Product form & Market region & Product use \\
\hline Live quality (Ezo quality) & Japan & Sushi, sashimi \\
\hline Live premium (Tokobushi quality) & US, Hong Kong & Grilled, steamed \\
\hline Live petite (Futokoboshi quality) & US, Hong Kong & Traditional Asian cuisine \\
\hline Premium fillet (Fresh/frozen) & US, France & $\begin{array}{l}\text { Traditional US restaurant } \\
\text { cuisine }\end{array}$ \\
\hline Retail sales & US, France & $\begin{array}{l}\text { US restaurants and } \\
\text { traditional European cuisine }\end{array}$ \\
\hline Petite fillet (Fresh/frozen) & US, France & \\
\hline Processed whole foot (canned) & $\begin{array}{l}\text { China, Hong Kong, } \\
\text { and Southeast Asia }\end{array}$ & \\
\hline
\end{tabular}

search and development projects, or production hatcheries, are in operation in Australia, the British Isles, Japan, Canada, Chile, France, Mexico, Taiwan, and the United States (California), The Philippines (Ebert \& Houk, 1984; Cheng Chen, 1984; Chew, 1984; Oakes \& Ponte, 1996; SEAFDEC, 2000, Ebert, 2001; Awaji \& Hamano, 2004). Recently, abalone has been introduced for farming in some Pacific countries (Bell \& Gervis, 1999).

Total world abalone aquaculture production in 2002 was 8,696 MT with value approximately US $\$ 0.8$ billion (Gordon \& Cook, 2004). Previously, abalone production was dominated by three main countries, Mexico, Japan, and Australia, each with a landing of over 5,000 metric tons annually and mainly come from direct catch from the wild (Chew, 1984; Oakes \& Ponte, 1996) (Table 3).

Recent data showed that China and Taiwan are the main contributors for abalone landing from aquaculture with over 300 farms and a total production of approximately 4,500 metric tonnes (Gordon \& Cook, 2004). In California, abalone aquaculture production for the year 1998 was 162,000 pounds valued at US\$2.4 million. Abalone aquaculture production in South Africa in 1998 reached 22 MT with value nearly US\$1 million (Hoffman et al., 2000). Australia only produces $89 \%$ tonnes (ca. 1\% of world production of 7,775 tonnes) from abalone aquaculture in 1999 (Fleming, 2000). Most of cultured abalone is temperate species as the development of culture techniques originated from temperate region. However, intensive researches of culture techniques of tropical abalone species are being conducted in some Southeast Asian countries such as Vietnam, Thailand, The Philippines, and Indonesia. The Philippines even has developed and implemented the culture of tropical species $H$. asinina (SEAFDEC, 2000).

Table 3. Main producers of abalone in the world in 1993 (From Oakes \& Ponte, 1996)

\begin{tabular}{llrc}
\hline \multicolumn{1}{c}{ Country } & \multicolumn{1}{c}{ Species } & $\begin{array}{c}\text { Annual supply } \\
\text { (MT) }\end{array}$ & $\begin{array}{c}\text { 1993 price } \\
\text { (\$US MT-1) }\end{array}$ \\
\hline Mexico & H.fulgens, H. rufescens, H. cracherodii & 2,000 & 24,000 \\
South Afric a & H. midae & 600 & 25,000 \\
Australia & H. laevigata, H. ruber, H. roei & 6,300 & 21,850 \\
Hong Kong & H.diversicolor diversicolor & 567 & 22,200 \\
& H.diversicolor supertexta & & \\
Japan & H.discus hannai, H.discus & 4,000 & 66,000 \\
USA & H. rufescens, H. carcharoides & 350 & 25,000 \\
& H. sorenseni, H. fulgens & & \\
\hline
\end{tabular}


High survival and growth rate are the main aims of abalone aquaculture. To achieve this, nutritional value of feed becomes important. Abalones are slow growing, therefore reduction of production time because of increased growth rate as a result of food supply, has large cost benefits to the farmer (Daume, 2003). Despite rapid development of abalone aquaculture, the studies of nutrition requirements for abalone post larvae and early juveniles have just began to start in early 90's. Some earlier studies have been attempted only to investigate the cues that driven abalone larval settlement. At this stage high mortality usually occurs in culture condition where natural cues of settlement are lack or absence (Slattery, 1992). Therefore by understanding the cues of larval settlement, mortality rate will be decreased as low as possible. Early settlement larvae of abalone usually fed on diatom (Ebert \& Houk, 1984). Ebert (1992) stated that juvenile abalones feed on rock-encrusting coralline algae and on diatom and bacterial films. Adult abalones feed primarily on loose pieces of marine algae drifting with the surge or current. Large brown algae such as giant kelp, bull kelp, feather boa kelp and elk kelp are preferred, although other species of algae may be eaten at various times. Furthermore, some researches have been conducted to formulate artificial foods for abalone post larvae. However, very little is known about the nutritional properties of food required for abalone growth (Fleming \& Hone, 1996). This present paper overview the studies on nutrition requirements of abalone post larvae and juveniles so far and include some preferred diatom species as feed for post larvae of abalone.

\section{GENERAL CULTURE METHOD}

\section{Morphology and Behaviour of Larvae}

Slattery (1992) stated that as marine invertebrate, abalone passed through two distinct processes during transformation from larvae to juveniles: settlement and metamorphosis. Garland et al. (1985) described that abalones genus Haliotis begin life as planktonic larvae but after several days they settle on and graze suitable benthic substrata, where over the next few weeks they metamorphose into the creeping juvenile form. At this stage high mortality usually occurs in culture condition where natural cues of settlement are lack or absence (Slattery, 1992). After achieving settlement stage, food of post larvae become another important consideration as their yolk reserve utilised. In this stage the gut is developed and larval start to feed (Ebert \& Houk, 1984).

Ebert (1992) described abalones as very fertile marine invertebrates that reach sexual maturity at a small size and increases exponentially with size. Abalones reproduce through external fertilization, bigger individuals may spawn more eggs than small one. For example 1.5 inch abalone may spawn 10,000 eggs or more at a time, while an 8 inch abalone may spawn 11 million or more eggs (Ebert, 1992). In temperate region, spawning season is species specific. Black, green and pink abalones spawn between spring and fall, while pinto abalone spawn during the summer. Red abalones in some locations spawn throughout the year. Abalone is planktonic larvae after hatching from fertilized eggs. The abalones are then settled after shell formation (Ebert, 1992).

\section{Settlement of Abalone Larvae}

In natural environment, abalones settle on coralline red algae (Daume, 2006). The occurrence of four buds on the cephalic tentacles is a good indicator of settlement phase in captivity. Also number of chitinised teeth on radula can be used as indicator. Most abalone larvae with five and six rows will settle and larvae with three or four rows can settle (Tong \& Moss, 1992).

Earlier researches on the settlement of abalone larvae were started to investigate the habitat requirements of newly settled larvae in artificial condition, which is considered as critical stage in managing of natural stocks and developing of methods for their artificial culture (Sheperd \& Turner, 1985; Searcy-Bernal et al., 1992). Fleming \& Hone (1996) found that farmers have experienced considerable larval mortalities up to $90 \%-95 \%$ in the first few weeks after settlement. It is suggested that the environmental and nutritional requirements of newly-settled abalone larvae are the major factors that have to be focused in research (Fleming \& Hone, 1996). Moreover SearcyBernal et al. (1992) stated that environmental cues were important to induce metamorphosis in abalone larvae hence increase survival rate.

Three methods of induction are commonly used to accelerate metamorphosis and settlement of abalone larvae in artificial environment 
i.e: diatom film, mucus and gamma aminobutryc acid (GABA) (Table 4, Searcy-Bernal et al., 1992). Another method like encrusting coralline algae was also used but not common in cultured abalone (Castell, 2003). Settlement of abalone larvae in response to diatom films depends on the abalone species, the diatom species tested, and the density of the diatoms on the plates (Daume et al., 1999).

Searcy-Bernal et al. (1992) stated that the diatom-film method was originally developed in Japan and is also practised in Taiwan, USA, New Zealand, Mexico, and other countries. Similarly, the mucus method, also developed by the Japanese, is currently used in Japan, Korea, and Australia. Currently, mucus and diatom films methods are combined to enhance settlement and larval survival in Japan (Daume et al., 2000). Therefore, these two methods are not discussed separately. On the other hand, the GABA method, an inexpensive amino acid related to the natural inducer molecule, was proposed after its first trial success in the USA in small-scale laboratory experiments with antibiotics and excellent environmental quality. However, several early trials in commercial scale met unexpected poor results. It is suggested that the presence of microbial biota was interfered with the GABA induction, thus it would need antibiotics to succeed (SearcyBernal et al., 1992). Different results were obtained by hatcheries with different methods (Castell, 2003).

Diatom films are commonly used in abalones hatchery to induce the settlement of lar- vae, however, the result is highly variable. Studies by Searcy-Bernal et al. (1992) demonstrated that the conventional diatom-film method was the least efficiency in inducing metamorphosis for red abalone (Haliotis rufescens). Similar result was obtained by Takami et al. (1997) in inducing settlement of $H$. discus hannai on plate with single diatom Cocconeis scutellum var. parva. The reason for this might be because that settlement of abalone larvae in response to diatom films depends on the abalone species, the diatom species tested, and the density of the species on the plates as studies by Daume et al. (1999). Also, single diatom may not suitable as food for newly settled abalone, therefore, diatom plates usually pregazed by larger juveniles of abalone to induce settlement and also to provide initial feed for newly settled larvae (Takami et al., 1997). Although the studies by Searcy-Bernal (1992) found that mucus had an intermediate efficiency to induce settlement and metamorphosis in red abalone ( $H$. rufescens), but the use of mucus to induce larval settlement was the most efficient in terms of growth and survival (Castell, 2003). This method commonly used in Japan where small juveniles or adult abalones (>10 $\mathrm{mm} \mathrm{SL}$ ) allowed to graze on plates conditioned with diatoms before placing them in settlement tanks. The bacteria present in the mucus left by juvenile with the same species combined with the mucus from diatoms are suggested to provide good source of food for the newly settled larvae (Castell, 2003; Takami \& Kawamura, 2003; Daume et al., 2004).

Table 4. Methods currently used to induce metamorphosis and settlement in abalone (Haliotis spp.) culture (From Searcy-Bernal et al., 1992)

\begin{tabular}{|c|c|c|}
\hline Method & Description & Observations \\
\hline Diatom-film & $\begin{array}{l}\text { Plates or tanks are covered with a layer } \\
\text { of bacteria and benthic diatoms, either } \\
\text { by allowing a gentle flow of filtered sea } \\
\text { water or by inoculating cultured diatoms }\end{array}$ & $\begin{array}{l}\text { Conventional method } \\
\text { Widespread use }\end{array}$ \\
\hline Mucus & $\begin{array}{l}\text { Juvenile or adult abalones are kept for } 24 \\
\text { hours on surfaces previously colonized } \\
\text { by mic roflora to allow secretion of mucus } \\
\text { trail }\end{array}$ & $\begin{array}{l}\text { Possible nutritional role of } \\
\text { mucus } \\
\text { Used mainly in Japan and } \\
\text { Korea }\end{array}$ \\
\hline GABA & $\begin{array}{l}\text { GABA is added to settlement tanks at a } \\
\text { final concentration of } 1 \mu \mathrm{M} \text {. Larvae must } \\
\text { be exposed to this stimulus for at least } \\
20 \text { hours }\end{array}$ & $\begin{array}{l}\text { Does not require the } \\
\text { mic robial film } \\
\text { Used in some hatcheries in } \\
\text { the USA }\end{array}$ \\
\hline
\end{tabular}


Further studies then were concentrated to find out preferred diatom species of inducing settlement of abalones larvae. Takami et al. (1997) revealed that settlement rates on the diatom (C. scutellum var. parva) and diatom and mucus (C. scutellum var. parva coated with grazing mucus) substrata were significantly higher than on the mucus substratum which was secreted by larger abalone during crawling without feeding. This result suggested that dominant diatoms, such as Cocconeis spp., on conditioned plates have an inductive potential for settlement of veliger larvae. Moreover, Daume et al. (2000) also demonstrated that although larvae of the Australian abalone $\mathrm{H}$. rubra settlement was very low on single species diatom films, the settlement increased in mixed diatoms films depends on the species combination. The highest settlement was achieved with a mixed film of Navicula sp. and Amphora sp. Five and ten-day-old germlings of Sporolithon durum induced settlement of the abalone $H$. rubra. However, the settlement rate was significantly lower on germlings than on the whole thallus of the alga. Germlings inoculated with the diatom Navicula sp. induced higher settlement than films of the diatom species alone. High settlement of up to $52 \%$ was also achieved with germlings of the green alga Ulvella lens. Settlement was reduced on U. lens squares inoculated with the diatom Navicula $\mathrm{sp}$. but higher than on films of the diatom alone. The settlement can be enhanced if $U$. lens was pregrazed by conspecific abalone (Daume et al., 2004). Furthermore, hatcheries in Japan successfully settle larvae of the abalone $H$. discus hannai onto plates encrusted with the green alga Ulvella lens, which have been previously grazed by abalone juveniles (Daume, 1999).

Although not commonly used in commercial hatchery, crustose coralline algae (CCA) has been successfully implemented to induce settlement of some species of abalone in artificial environment such as $H$. rubra, $H$. discus hannai and H. rufescens (Morse \& Morse, 1984; Daume, 1999; Takami \& Kawamura, 2003). Post larvae abalone do not utilize the CCA fragment it self but use the extra cellular product and bacteria on CCA as food (Takami \& Kawamura, 2003). The effects of bacteria and microorganisms on settlement and metamorphosis of abalone were studied by several scientists. Garland et al. (1985) stated that microorganisms can be of great importance for the normal development of very young marine invertebrates.
They found that $H$. ruber grazes, and presumably utilizes, material from the surface of crustose coralline algae from Tasmanian waters. It appears a general finding for Haliotis that postlarval and juvenile forms can graze very small items present on local benthic substrata and use them for adequate nutrition. However the nutrition composition of crustose coralline algae was not observed in these studies. This finding was in agreement with Morse \& Morse (1984) who found that crustose red algae induce substratum-specific settlement, attachment and metamorphosis of the planktonic larvae of $H$. rufescens Swainson upon direct contact by the larvae with the algae. Studies by Daume (1999) found that $H$. rubra did not respond to films of any diatom species tested, but settled on the natural settlement surface, the nongeniculate coralline red alga Phymatolithon repandum.

Searcy-Bernal et al. (1992) stated that the GABA method was the most efficient to induce settlement of red abalone (Haliotis rufescens). The settlement and metamorphosis was consistently higher even when used in the presence of bacteria without using antibiotics. The research with red abalone has shown that GABA is an excellent inducer under most conditions, but high postlarval mortality may occur afterwards. The possibility of a deleterious postmetamorphic effect of GABA on postlarval survival has been ruled out by experiments with antibiotics in which excellent survival (93\%) has been observed one month after GABA induction (Searcy-Bernal et al., 1992). In accordance with chemical using to induce larval settlement of abalone, Kang et al. (2004) found that $H$. discus hannai can be induced to settle with bromomethane and potassium chloride. Bromomethane displays verifiable effects on settlement promotion in 600-900 mg/L while potassium chloride on metamorphosis promotion in 14-19 mM concentration level (Kang et al., 2004). However, this is the only experiment found in using such chemicals and was conducted at laboratory condition. More studies are needed to clarify these techniques before commercial trial is conducted.

Recent studies in Japan have been developed to replace live microalgae with alternative settlement cues. Daume (2006) summarized that in the earlier studies, an alginate gel solution containing micro particulate diets was pasted onto settlement plates. In more recent studies settlement plates are sprayed with a solution of agar and one of the following: dried 
algal powder (Spirulina platensis, Chlorella vulgaris, Undaria pinnafifida), dried natural diatom powder, formulated diet and two different concentrations of "[gamma]-aminobutyric acid (GABA), each with and without antibiotics, and compared with negative (clean plates) and positive (living natural diatom biofilms). Stott et al. (2004) showed that there was no significant difference in settlement rates between the microalgae powder treatments and the living natural biofim but both supported significantly higher rates when compared with the negative control and GABA treatments. Another study demonstrated that pregrazing of plates by conspecific juveniles covered with microalgal powder/ agar solution enhanced larval settlement significantly ( $85 \%$ vs. $30 \%$ on grazed and ungrazed plates respectively) (Daume \& Ryan, 2004). This system shows some potential, however, mechanized and cost-efficient ways of spraying the plates need to be developed before it becomes viable commercially (Daume, 2006).

Some studies explained above shown that diatom and mucus were the best combination in inducing settlement of abalone larvae. Some species of diatom such as Cocconeis spp., Navicula sp. and Amphora sp. showed better performance when used to induce abalone larvae settlement when combined with mucus of larger abalone. Newly settled abalone utilized extracelullar component of crustose corraline algae, diatom, trail mucus, and macroalgae but larger post larvae $(>0.7 \mathrm{~mm})$ need adequate supply of benthic diatoms on settlement plate as food to support optimal growth (Takami \& Kawamura, 2003). More detail about nutritional and physical characteristics of benthic diatoms use as food of abalone larvae in captivity will be outlined in the next section.

\section{FOODS FOR ABALONE POST LARVAE AND JUVENILES}

Kawamura et al. (2001) outlined the feeding habit of abalone. Particle in water column is the food of abalones after metamorphosis when larval abalone shed the velum, develop enlarged gills and a foot, and peristomal shell formation is initiated (Takami \& Kawamura, 2003). After settlement, they fed on benthic diatoms, and post-larvae smaller than approximately $0.8 \mathrm{~mm}$ shell length (SL) grow at similar rates regardless of diatom strain, provided they receive an adequate supply of biofilm material. After bigger size reached, they become responsive to the 'digestibility' of diatom di- ets and grow more rapidly on efficiently digested diatom strains. At approximately $5-10$ $\mathrm{mm} \mathrm{SL}$, abalones shift the diet from a diatom dominated diet to a macroalgae-dominated diet (Kawamura, 2001).

Borowitzka (1997) stated that there are two main sources of algal species used in aquaculture. These are: (1) natural populations of phytoplankton, either as they are found in nature or from cultures enriched by adding nutrients and (2) unialgal cultures. Regarding abalone culture most of their first foods come from natural populations of benthic diatoms occur in plastic plates. The diatom film on the plates is maintained through passive seeding through seawater flow into the nursery tank, adding nutrients and shading the tank to manipulate light intesity (Daume, 2003). This consequently, makes assessments of feeding habits and dietary value of benthic diatoms difficult to perform (Kawamura et al., 1995). Moreover Daume (2003) stated that this process is unpredictable and larval settlement rates can be low ( $1 \%$ to $10 \%$ of larvae). Therefore some experiments have been conducted to culture single species of microalgae to induce settlement as well as food for abalone post larvae (Daume, 2003). Recent studies focused on revealed nutritional value of cultured benthic diatoms and factors affecting digestion of microalgae by abalone (Kawamura et al., 1998; Daume et al., 2004; Daume, 2006).

\section{Benthic diatoms and macroalgae}

Benthic diatoms and macroalgae are two natural foods of abalones in hatchery. Benthic diatoms are important food for newly settled abalones while larger juvenile feed on macroalgae (Kawamura et al., 1995; Daume et al., 2000; Daume, 2006). Diatoms are the most widespread group of algae and can be found in all habitats from seawater to freshwater. The largest part of diatom are live pelagically in open ocean but some are inhabit water floor and even rocks as benthic diatom (Mann, 1999).

Considering their natural abundance in coastal reefs where abalones occur, diatoms, particularly benthic diatoms, are important algae group in abalone lifecycle particularly abalone post larvae (FAO, 1990; Kawamura et al., 1995). Nie (1992) stated that $H$. discuss hannai use benthic diatoms as food frequently because diatoms are common epiphytes on preferred algae and also they are the only food available when algae are scarce or absent. 
Furthermore based on their feeding behaviors, abalones prefer benthic diatoms than pelagic diatom (Kawamura et al., 1995; Knaeur et al., 1996). However, the abalones showed a selection behavior to benthic diatoms offered depend on digestibility and the size of post larvae. Matthew \& Cook (1995) suggested that newly settled post larvae should be supplied with prostrate diatoms such as Cocconeis sp. because not only prostate genera is not affected by pregrazing during settlement phase but also newly settled abalone prefer this genera as food. Furthermore, mixed diatom diet supports better growth than unialgal diet (Gordon et al., 2006).

After settlement and post larvae stage, abalone juveniles usually feed on macroalgae. Naturally, abalone juveniles feed on algae such as Undaria and Laminaria for H. discus hannai (Lee, 2004). Some studies have been attempted to culture macroalgae as foods for abalone juveniles (Rosen et al., 2000; Vierra et al., 2005). Culture of Ulva spp., Gracilaria cornea, Hypnea spinella, P. mollis, and Hypnea musciformis in nutrient rich water of intensive recirculation systems provided continuous supply and better quality food for some abalone species such as $H$. tuberculata, $H$. discus hannai, $H$. roei, Haliotis rufescens, and $H$. tuberculata coccinea (Rosen et al., 2000; Vierra et al., 2005).

\section{Physical characteristics}

Kawamura et al. (1995) suggested that the physical charasteristics of the diatom species as to whether the cell wall of the diatom is ruptured on grazing or not determine digestion efficiency, thus growth rate of abalones post larvae. Some studies also suggested that the diatom cell size, attachment strength, frustule strength and post-larval size can influence the digestion of diatoms (Kawamura et al., 1998; Daume et al., 2000). Also, density of diatom supplied to abalone post larvae and light intensity are important in determining early growth of abalone (Daume, 2003). As stated previously that abalone post larvae use extracellular mucus and bacteria for their early growth. Therefore, the higher the density of diatom may support better growth and survival at early stage of abalone lifecycle.

Juveniles of abalone prefer tender macrolagae as their food. Some macroalgae such as G. cornea, was not preferred as diet of abalone because it has harder texture compared to other macroalgae and its ash content prevent consumption by abalone (Viera et al., 2005). Fleming (1995) stated that the preference food for abalone may be influenced by food availability, avoidance of chemicals deterrents and an inability to consume tough foods. This is in agreement with Nie (1992) who stated that foliose and tender species were preferred as food by $H$. discuss hannai. Species such Macrocystis pyrifera, Undaria pinnatifada, Lamonia japonica, Monostroma, and Ulva were more frequently eaten than $S$. thunbergii, S. pallidum, and Gelidium amansii. Studies by McShane et al. (1994) confirmed this finding with $H$. rubra which select their foods based on macroalgal textures, tough food usually less eaten than tender food.

\section{Nutrient characteristics}

Nutritional value of microlagae is affected by various factors include harvest stage, light intensity, nutrient concentrations and culture method. Some studies indicate that changes in light intensity and nitrate concentration in diatom culture systems can have a dramatic effect on growth, grazing rates and particularly survival of postlarval and juvenile abalone (Daume, 2006).

Algae for abalone characterized by low lipid and high carbohydrate content (Rosen et al., 2000; Viera et al., 2005). Protein content of macroalgae for abalone is ranged from $20 \%$ 35\% (Rosen et al., 2000; Viera et al., 2005). Nitrogen is the most important element of protein and also the important compound determining both quality and digestibility of algae (Fleming, 1995; Hertrampf \& Piedad-Pascual, 2000). Nitrogen also found to enhance protein level of macrolagae (Viera et al., 2005) thus accelerates growth of abalone post larvae at some level. Studies by Daume et al. (2003) found that amino acid profile was highly affected by nitrogen level of culture media of microalgae, Navicula sp. Abalone feed on algae cultured in higher nitrogen media showed high survival than that feed on algae in lower nitrogen media. High survival was correlated with total amino acid content of algae. However, significant correlation was not found between total amino acid content and low survival of abalone. It is suggested that nitrogen concentration should be maintained at optimal rate between $2-12 \mathrm{mg} \mathrm{NO}_{3} \mathrm{~N} / \mathrm{L}$ for algal culture media. Higher concentration is not recommended as either TAA and growth rate of abalone did not increase (Daume et al., 2003). Watson et al. (2004) found that light intensity 
can affect the growth of Navicula jeffreyi but not Cocconeis sp. making this species suitable for shading nursery condition. However, when fed to $H$. laevigata post larvae there was no difference in growth rate between two species but low survival rate was observed in post larvae fed on N. jeffreyi. Further studies revealed that $N$. jeffreyi cultured in high light intensity was lower in protein and higher in carbohydrates and fat. Juveniles grazed larger numbers of diatom cells when the protein content was low, possibly compensating for the lower protein levels (Watson et al., 2005; Daume, 2006). Therefore maintaining consistent supply of microlagae under suitable culture condition is important in commercial nurseries of abalones.

Mai et al. (1996) found that all macroalgae used as food for $H$. tuberculata L. and $H$. discus hannai Ino were low in C22 fatty acids. The red algae, $P$. pulmuta, was characterised by the highest proportion of 20:5n. C18 and C20 fatty acids were dominant in brown algae A. esculenta, L. digitata, and $L$. saccharina. In the green alga, U. luctuca, however, the dominant PUFA were $\mathrm{C} 16$ and $\mathrm{C} 18$ fatty acids.

\section{Formulated Foods/Artificial Diet}

The development of artificial diet mainly is driven by economic feasibility of abalone farming. The limited supply and quality of diatoms in hatchery are also some reasons of shifting to artificial diet (Kneur et al., 1996; Daume \& Ryan, 2004). Also, an ecological concern of harvesting macrolagae from the wild has led to development of artificial diet for juveniles of abalone (Grubert et al., 2004). Japan and China are both the major producer and user of artificial diet for abalone although still in development stage. Dry, pelleted abalone feeds are widely used include in Japan, China, Australia, New Zealand, and South Africa (Fleming et al., 1996; Bautista_Terruel \& Millamena, 1999). Despite the rapid research and development of formulated abalone diet some problems still occur. The availability and behaviour in the tank system, and the problems of waste removal and aeration associated with artificial diets are considered as the greatest limiting factor in using artificial feeds (Fleming et al., 1996).

\section{Physical characteristics}

Generally artificial feeds for abalone culture are pelleted and extrusion feeds. Most of composition of the foods is protein that come from fish meal. However, some researches are in progress to found alternative source of protein that not detrimental to environment such as soybean (Fleming et al., 1996). Other compound such as carbohydrate and lipid also occur. All that components are held together by an alginate binder and sometimes vitamins and minerals are added (Fallu, 1991). Lipid source is come from fish oil, vegetable oil or combination of these (Fleming et al, 1996) while carbohydrate comes from starch or dextrin from plants (Fallu, 1991).

\section{Nutrient characteristics}

Nutrient properties of formulated abalone feeds resemble their proximate composition. They contain a high protein and carbohydrate content and a low lipid and fibre content. The protein content varies considerably from about $20 \%$ to $50 \%$, averaging around $30 \%$ crude protein. Lipid content ranges from $1.5 \%$ to $5.3 \%$, averaging around $4.0 \%$. Carbohydrate makes up the bulk of the diets, ranging from $30 \%$ to $60 \%$ and averaging $47 \%$. Crude fibre content is generally low $(0 \%$ to $3 \%)$ as the capacity for abalone to digest fibre is limited (Fleming et al., 1996).

\section{Nutritional requirements for abalone post larvae and juveniles}

The economic success of abalone culture is partly determined by nutritional quality of the feed (Lee, 2004). Studies on nutrition requirement of abalone post larvae and juveniles showed that nutritional requirement is species specific. This may be due to either different geographic distribution (temperate vs. tropic) or culture method (intensive vs. extensive). Generally, natural foods are nutritionally lower than formulated foods. This because nutrition of formulated foods can be manipulated and developed to fulfill abalone requirements for optimal growth and development. For example macroalgae Undaria contain $12.8 \%$ crude protein, $1 \%$ crude lipid, while formulated foods were made to contain $34.1 \%$ crude protein and $7.5 \%$ crude lipid. H. discus hanai fed on formulated food showed better growth and survival than that fed on natural diet (Lee, 2004). Similar result was obtained for juvenile $H$. midae fed on diatoms and pelleted foods (Kneur et al., 1996) and $H$. asinina fed on artificial diet and seaweed (Bautista-Terruel \& Millamena, 1999). In aquaculture, it is suggested that the use of artificial feeds is more feasible than natu- 
ral foods although some factors such listed previously should be examined carefully in commercial use.

\section{Carbohydrate}

Fallu (1991) stated that carbohydrate in formulated diet for abalone can be ranged from $5 \%-30 \%$ of the total diet. However, very little is known about the carbohydrates requirements in mollusk culture including abalone. In abalone farming carbohydrate is considered as inexpensive energy source (Hertrampf \& Piedad-Pascual, 2000). Avalaible information usually species specific and can not be used for generalization.

Lee (2004) showed that $H$. discus hannai use carbohydrate more efficiently than lipid for energy source. This may be due to digestive enzymes that favour carbohydrates breakdown than lipids. Also, carbohydrates are the main composition of algae as the main food of abalones in the wild (Mai et al., 1995). Carbohydrate level range from $10 \%-25 \%$ can be digested properly by $\mathrm{H}$. discus hanai resulting in considerable high growth rate (Lee, 2004).

\section{Protein}

Cultured abalone requires less protein than fishes because their feeding habit as herbivores. Although dietary protein of abalone is species dependant, generally they require protein not less than $30 \%$ in the diet (Hertrampf $\&$ Piedad-Pascual, 2000). Moreover, the differences of protein requirements between species may due to culture surroundings, abalone size, feeding trials period, digestible protein to energy ratio, the pattern of EAAs in the diets or statistical analysis used in the studies (Lee, 2004).

H. midae were found to grow better on $358.7 \mathrm{~g} \mathrm{~kg}-1 \mathrm{DM}$ (dry matter) dietary protein or $36 \%-47 \%$ of crude protein level in the diet. The grow was reduced if they fed on dietary protein of $280.7 \mathrm{~g} \mathrm{~kg}-1 \mathrm{DM}$ and depressed if they fed with dietary protein of $5 \mathrm{~g} / \mathrm{kg}$ (Sales et al., 2003). Lee (2004) summarized from various study that $H$. discus hannai required $20 \%-37 \%$ crude protein. $H$. kamtschatkana and $H$. laevigata required $30 \%$ and $27 \%$, respectively. $H$. asinina required $27 \%$ of crude protein in the diet (Bautista-Terruel \& Millamena, 1999). Mai et al. (1995) found that $35 \%$ dietary protein from good quality sources is recommended for the maximum growth of $H$. tuberculata and $H$. discus hannai, and, if di- etary protein is reduced from $35 \%$ to $25 \%$, the growth of these abalones may be depressed with $5 \%$ likelihood. $H$. fulgens grow better at protein level of $40 \%-45 \%$ but the use of $40 \%$ level was recommended as PER ratio was better at that level (Gomez- Montes et al., 2003).

\section{Lipid}

Lipid, particularly those rich in PUFA and HUFA $n-3$ and $n-6$ are important in reproduction and larval development of abalone (DurazoBeltran et al., 2004). Hertrampf and PiedadPascual (2000) suggested that formulated diet for abalone should contain at least $5 \%$ of lipid. Lipid supplementation for temperate abalone should have low melting point to reduce fatty flesh.

Mai et al. (1995) showed that the lipid requirements of abalone are typical of herbivores. The dietary lipid between $3 \%-5 \%$ was recommended to formulate artificial diets for abalone particularly for $\mathrm{H}$. discus hannai (Mai et al., 1995). Further studies by Mai et al. (1996) showed that $H$. discus hannai require both $\mathrm{n}-3$ and n-6 fatty acids to enhance growth while $H$. laevigata only require $\mathrm{n}-3$ fatty acids for better growth.

\section{Vitamins and Minerals}

Vitamins are required by mollusks to prevent deficiency symptoms. However, as cultured abalones are mainly fed on natural food, their vitamins requirement may be met (Hertrampf \& Piedad-Pascual, 2000).

Some minerals such as calcium and phosphorus are two of the major constituents of the inorganic portion of feeds (Tan et al., 2001). Abalones do not require high concentration of calcium and phosphorus in their diets. Coote et al. (1996) reported that green lip abalone $H$. laevigata only need $0.5 \%$ of calcium in their diets and by adding $0.7 \%$ of phosphorus to the diet can improve the growth rate. Calcium supplementation in the diet of $H$. discuss hannai did not affect the survival, growth, or proximate composition of the abalone. However, proper phosphorus supplementation (up to $1.5 \%$ ) in the diet showed significant effect on the growth rate of this species (Tan et al., 2001).

\section{CONCLUSION}

Based on discussion of nutrition requirement of abalone post larvae and juveniles 
above some conclusion can be drawn as follows:

1. Settlement phase is a critical stage in abalone hatchery. Applying the right settlement cues such as benthic diatoms plates pregrazed by juveniles and adult abalones is recommended to achieve high survival rates and better growth.

2. Balanced nutrition in the diet of cultured abalone is required to ensure optimal growth and survival in captivity. As herbivores abalones require low protein level ( $27 \%-45 \%)$ because they can utilize carbohydrate as energy source efficiently and $3 \%-5 \%$ of lipid is recommended for normal growth and development of abalone.

3. Abalone aquaculture will develop rapidly in the future because wild harvest is not sufficient to fulfill high market demand of abalone.

4. More researches are needed to develop artificial feed of abalone that met the culture condition of abalone.

\section{REFERENCES}

Awaji, M., and K. Hamano. 2004. Gonad formation, sex differentiation and gonad maturation processes in artificially produced juveniles of the abalone, Haliotis discus hannai. Aquaculture. 239: 397-411.

Bautista-Teruel, M.N., and O.M. Millamena. 1999. Diet development and evaluation for juvenile abalone, Haliotis asinina: protein/ energy levels. Aquaculture. 178: 117-126.

Bell, J.D., and M. Gervis. 1999. New species for coastal aquaculture in the tropical Pacificconstraints, prospects and considerations. Aquaculture International. 7: 207-223.

Borowitzka, M.A. 1997. Microalgae for aquaculture: Opportunities and constraints. J. of Applied Phycology. 9: 393-401.

Castell, L. 2003. Marine Gastropods in Southgate, P.C., Lucas, J.S. (eds). Aquaculture Farming aquatic animals and plants. Blackwell Publishing. p. 467-487.

Chew, K.K. 1984. Recent advances in the cultivation of mollusks in the Pacific United States and Canada. Aquaculture. 39: 6981.

Coote, T.A., P.W. Hone, R. Kenyon., and G.B. Maguire. 1996. The effect of different combinations of dietary calcium and phosphorus on the growth of juvenile Haliotis laevigata. Aquaculture. 145: 267-279.
Daume, S., S. Brand-Gardner, and Wm.J. Woelkerling. 1999. Preferential settlement of abalone larvae: diatom films vs. non-geniculate coralline red algae. Aquaculture. 174: 243-254.

Daume, S., A. Krsinich, S. Farrell, and M. Gervis. 2000. Settlement, early growth and survival of Haliotis rubra in response to different algal species. J. of Applied Phycology. 12: 479-488.

Daume. S. 2003. Early life history of abalone (H. rubra, H. laevigata): Settlement, survival and early growth. Final report for FRDC Project 1998/306. Department of Fisheries Western Australia. 110 pp.

Daume, S., S. Huchette, S Ryan, and R.W. Day. 2004. Nursery culture of Haliotis rubra: the effect of cultured algae and larval density on settlement and juvenile production. Aquaculture. 236: 221-239.

Daume, S., and S. Ryan. 2004. Nursery culture of the abalone Haliotis laevigata: larval settlemet and juvenile production using cultured algae or formulated feed. J. Shellfish Research. 23: 1,019-1,026.

Daume, S. 2006. The roles of bacteria and micro and macro algae in abalone aquaculture: a review. J. of Shellfish Research. 25: $151-157$.

Ebert, E.E., and J.L. Houk. 1984. Elements and innovations in the cultivation of red abaIone Haliotis rufescens. Aquaculture. 39: 375-392.

Ebert, E.E. 1992. Abalone aquaculture: a North America regional review in Sheperd, S.A., Tegner, M.J., Guzman del Proo, S.A. (Editors). Abalone of the World, Biology, Fisheries and Culture. Proceedings of the $1^{\text {st }}$ International Symposium on Abalone $1989 \mathrm{La} \mathrm{Paz}$ Mexico. Fishing News Books. Cambridge.

Ebert, E.E. 2001. Culture of Abalone. California's Living Marine Resources: A Status Report. California Department of Fish and Game.

FAO. 1990. Training Manual on Artificial Breeding of Abalone (Haliotis discus hannai) in Korea. Avalaible online at http:// www.fao.org/docrep/field/003/AB731E/ AB731E00.htm\#TOC.

Fleming, A.E., and P.W. Hone. 1996. Introduction: Abalone Aquaculture. Aquaculture. 140: 1-4.

Fleming, A.E., R.J. Van Bameveld, and P.W. Hone. 1996. The development of artificial diets for abalone: A review and future directions. Aquaculture. 140: 5-53. 
Garland, C.D., C.L. Cooke, J.F. Grant, and T.A. McMeekin. 1985. Ingestion of the bacteria on and the cuticle of crustose (non-articulated) coralline algae by post-larval and juvenile abalone (Haliotis ruber Leach) from Tasmanian waters. J. Exp. Mar. Biol. Ecol. 91: 137-149.

Gomez-Montes, L., Z. Garcla-Esquivel, L.R. D’Abramo, A. Shimada, C. Vasquez-Pelaez, and M. Teresa Viana. 2003. Effect of dietary protein:energy ratio on intake, growth and metabolism of juvenile green abalone Haliotis fulgens. Aquaculture. 220: 769780.

Gordon, H.R. and P.A. Cook. 2004. World abalone fisheries and aquaculture update: supply and market dynamics. J. Shellfish Res. 23: 935-939.

Gordon, N., A. Neori, M. Shpigel, J. Lee, and S. Harpaz. 2006. Effect of diatom diets on growth and survival of the abalone Haliotis discus hannai postlarvae. Aquaculture. 252: 225-233.

Hertrampf, J.W. and F. Piedad-Pascual. 2000. Handbook on ingredients for aquaculture feeds. Kluwer Academic Publishers. 573 pp.

Hoffman 1, L.C., J.J. Swart, and D. Brink. 2000. The 1998 production and status of aquaculture in South Africa. Water SA. 26: 133136.

Jarayabhand, P., and N. Paphavasit, N. 1996. A review of the culture of tropical abalone with special reference to Thailand. Aquaculture. 140: 159-168.

Kang, K.H., B.H. Kim, and J.M. Kim. 2004. Induction of larval settlement and metamorphosis of the abalone, Haliotis discus hannai larvae using bromomethane and potassium chloride. Aquaculture. 230: 249-259.

Kawamura, T., T. Saido, H. Takami, and Y. Yamashita. 1995. Dietary value of benthic diatoms for the growth of post-larval abaIone Haliotis discus hannai. J. of Experimental Marine Biology and Ecology. 194: 189-199.

Kawamura, T., R.D. Roberts, and C.M. Nicholson. 1998. Factors affecting the food value of diatom strains for post-larval abalone Haliotis iris. Aquaculture. 160: 81-88.

Lee, S.M. 2004. Utilization of dietary protein, lipid and carbohydrate by abalone $H$. discus hannai : a review. J. Shellfish Research. 23: 1,027-1,030.

Mai, K., J.P. Mercer, and J. Donlon. 1995. Com- parative studies on the nutrition of two species of abalone, Haliotis tuberculata $L$. and Haliotis discus hannai Ino. IV. Optimum dietary protein level for growth. Aquaculture. 136: 165-180.

Mai, K., J.P. Mercer, and J. Donlon. 1996. Comparative studies on the nutrition of two species of abalone, Haliotis tuberculata $\mathrm{L}$. and Haliotis discus hannai Ino. V. The role of polyunsaturated fatty acids of macroalgae in abalone nutrition. Aquaculture. 139: 77-89.

McShane, P.E., H.K. Gorfine, and I.A. Knuckey. 1994. Factors influencing food selection in the abalone Haliotis rubra (gastropoda). J. of Experimental Marine Biology and Ecology. 176: 27-37.

Mann, D.G. 1999. The species concept in diatoms. Phycologia. 38: 437-495.

Matthews, I., and P.A. Cook. 1995. Diatom Diet of Abalone Post-larvae (Haliotis midae) and the Effect of Pre-grazing the Diatom Overstorey. Mar Freshwater Res.46: 545548.

Morse, A.N.C. and D.E. Morse. 1984. Recruitment and metamorphosis of Haliotis larvae induced by molecules uniquely available at the surfaces of crustose red algae. J. Exp. Mar. Biol. Ecol. 75: 191-215.

Najmudeen, T.M. and A.C.C. Victor. 2004. Seed production and juvenile rearing of the tropical abalone Haliotis varia Linnaeus 1758. Aquaculture. 234: 277-292.

Nie, Z.Q. 1992. A review of abalone culture in China in Sheperd, S.A., Tegner, M.J., Guzman del Proo, S.A. (Editors). Abalone of the world: Biology, Fisheries and Culture. Proceedings of the $1^{\text {st }}$ International symposium on abalone $1989 \mathrm{La} \mathrm{Paz} \mathrm{Mexico.}$ Fishing New Books. Cambridge. p. 592602.

Oakes, F.R., D.R. Ponte. 1996. The abalone market: Opportunities for cultured abalone. Aquaculture. 140: 87-195.

Rosen, G., C.J. Langdon, and F. Evans. 2000. The nutritional value of Palmaria mollis cultured under different light intensities and water exchange rates for juvenile red abalone Haliotis rufescens. Aquaculture. 185: 121-136.

Sales J. 1; Truter, P.J.2; and P.J. Britz. Optimum dietary crude protein level for growth in South African abalone (Haliotis midae L.). Aquaculture nutrition. 9: 85-89.

SEAFDEC. 2000. Abalone seed production and 
culture. Aquaculture Department Southeast Asian Fisheries Development Center Tigbauan, lloilo, Philippines.

Searcy-Bernal, R., A.E. Salas-Garza, R.A. FloresAguilar, and P.R. Hinojosa-Rivera. 1992. Simultaneous comparison of methods of settlement and metamorphosis induction in the red abalone (Haliotis rufescens). Aquaculture. 105: 241-250.

Searcy-Bernal, R. 1996. Boundary layers and abalone postlarval culture: Preliminary studies. Aquaculture. 140: 129-137.

Slattery, M. 1992. Larval settlement and juvenile survival in the red abalone (Haliotis rufescens): an examination of inductive cues and substrate selection. Aquaculture. 102: 143-153.

Sheperd, S.A. and J.A. Turner. 1985. Studies on Southern Australian abalone (genus Haliotis) VI. Habitat preference, abundance and predators of juveniles. J. Exp. Mar. Biol. Ecol. 93: 285-298.

Stevens, M.M. 2003. Cultured Abalone (Haliotis spp.). Final report on Seafood Watch and Seafood Report. Monterey Bay Aquarium. $12 \mathrm{pp}$.

Stott, A.E., T. Takeuchi, and Y. Koike. 2004. Growth and survival of post larval abalone Haliotis diversicolor (Lischke) using an alternative culture method in the light and dark. J. Shellfish Res. 23: 957-961.

Takami, H., T. Kawamura, and Y. Yamashita. 1997. Survival and growth rates of post-larval abalone Haliotis discus hannai fed conspecific trail mucus and/or benthic diatom
Cocconeis scutellum var.Parva. Aquaculture. 152: 129-138.

Takami, H., and T. Kawamura. 2003. Review: Dietary Changes in the Abalone, Haliotis discus hannai, and Relationship with the Development of the Digestive Organ. JARQ 37: 89-98. http://www.jircas.affrc.go.jp.

Tan, B., K. Mai, and Z. Liufu. 2001. Response of juvenile abalone, Haliotis discus hannai, to dietary calcium, phosphorus and calcium/phosphorus ratio. Aquaculture. 198: $141-158$.

Tong, L.J., and G.A. Moss. 1992. The New Zealand culture system for abalone in Sheperd, S.A., Tegner, M.J., Guzman del Proo, S.A. (Editors). Abalone of the world : Biology, Fisheries and Culture. Proceedings of the $1^{\text {st }}$ International symposium on abalone. Fishing New Books. Cambridge. pp 583-591.

Viera, M.P., J.L. Go' mez Pinchetti, G. Courtois de Vicosea, A. Bilbao, S. Sua'rez, R.J. Haroun, and M.S. Izquierdo. 2005. Suitability of three red macroalgae as a feed for the abalone Haliotis tuberculata coccinea Reeve. Aquaculture. 248: 75-82.

Watson, D., S. Daume, J. Prince, L. Beazley, and B. Knott. 2004. The influence of light intensity on the density of different diatoms as feed for juvenile greenlip abalone (Haliotis laevigata). Aquaculture. 235: 345-359.

Zhang, G., H. Que, X. Liu, and H. Xu. 2004. Abalone mariculture in China. J. of Shellfish Research. 23: 947-951. 